\title{
PEMODELAN PROBABILITAS SEBARAN HABITAT UNTUK MENENTUKAN KAWASAN PRIORITAS KONSERVASI BURUNG RANGKONG GADING (Rhinoplax vigil) DI GEOPARK SILOKEK, KABUPATEN SIJUNJUNG
}

\author{
Rizki Atthoriq Hidayat $^{{ }^{*}}$, Natasyah Febriani ${ }^{1}$ \\ ${ }^{1}$ Program Studi Geografi, Fakultas Ilmu Sosial, Universitas Negeri Padang \\ *corresponding author : rizkiatthoriq99@gmail.com
}

\begin{abstract}
Helmeted hornbill is a protected species in Indonesia based on Law No. 5 of 1990 concerning Conservation of Living Natural Resources and their Ecosystems and Government Regulation No 7 of 1999 concerning Preservation of Plants and Animals. The habitat of the ivory hornbill is spread across five regions of the country, namely Myanmar, Thailand, Malaysia (Malayan Peninsula and Sarawak), Brunei, and Indonesia (Sumatra and Kalimantan). The Silokek Geopark area, Sijunjung Regency, West Sumatra Province is one of the areas identified as the habitat of Helmeted Hornbill. Apart from their unique physical form, this animal has an ecological function as a seed emitter in the forest. The utilization of Remote Sensing (RS) Technology and Geographic Information System (GIS) is highly needed to identify the distribution of the Helmeted Hornbill habitat distribution in this research. The data set used are Landsat OLI 8 imagery and geospatial data related to the Silokek Geopark. This study aims to determine priority area for the conservation of the Helmeted Hornbill in the Silokek Geopark area. By utilizing MaxEnt (maximum entropy) algorithm based on wildlife point, the probability of the distribution of hornbill habitat in the Silokek Geopark area can be predicted. Based on the research results, the potential areas for hornbill conservation in the Silokek Geopark area are located in the hills of protected forest area in the north and northeast part. The most influential parameters in this modeling are distance from river, slope, and land use.
\end{abstract}

Keywords: Habitat modeling, Helmeted Hornbill, Maximum Entropy (MaxEnt)

\begin{abstract}
ABSTRAK
Rangkong gading merupakan jenis satwa yang dilindungi di Indonesia berdasarkan Undang-Undang No. 5 Tahun 1990 tentang konservasi Sumber Daya Alam Hayati dan Ekosistemnya dan Peraturan Pemerintah No.7 Tahun 1999 tentang Pengawetan Tumbuhan dan Satwa. Habitat rangkong gading tersebar di lima wilayah negara, yaitu Myanmar, Thailand, Malaysia (Semenanjung Malaysia dan Serawak), Brunei, dan Indonesia (Sumatera dan Kalimantan). Kawasan Geopark Silokek, Kabupaten Sijunjung, Sumatera Barat merupakan salah satu wilayah yang teridentifikasi sebagai habitat rangkong gading. Selain bentuk fisiknya yang unik, satwa ini memiliki fungsi ekologis sebagai pemancar biji di dalam hutan. Pemanfaatan Teknologi Penginderaan Jauh (PJ) dan Sistem Informasi Geografis (SIG) sangat dibutuhkan untuk mengidentifikasi persebaran habitat rangkong gading dalam penelitian ini. Data yang digunakan adalah citra Landsat OLI 8 dan data geospasial terkait Geopark Silokek. Penelitian ini bertujuan untuk menentukan Kawasan prioritas konservasi Rangkong gading di kawasan Geopark Silokek. Dengan menggunakan algoritma Maximum Entropy (MaxEnt) berdasarkan titik satwa, maka dapat diprediksi probabilitas persebaran habitat rangkong di kawasan Geopark Silokek. Berdasarkan hasil penelitian, wilayah yang potensial untuk konservasi rangkong di kawasan Geopark Silokek terdapat di Kawasan perbukitan hutan lindung bagian utara dan timur laut. Parameter yang paling berpengaruh dalam pemodelan ini yaitu jarak dari sungai, lereng, dan penggunaan lahan.
\end{abstract}

Kata Kunci: Pemodelan habitat, Rangkong Gading, Maximum Entropy (MaxEnt) 


\section{PENDAHULUAN}

Rangkong gading tersebar di Sumatera dan Kalimantan, enam lokasi yang baru teridentifikasi kepadatan rangkong gading diantaranya tiga di daerah Kalimantan dan tiga di daerah Sumatera, mencakup TN kutai, Barito Ulu, International Corporation Indonesia di Kalimantan Timur, hutan harapan - Jambi, Taman Nasional Bukit Barisan Selatan (TNBBS), dan seluruh Provinsi Lampung. Rangkong gading umumnya menyukai di daerah hutan yang jauh dari aktivitas manusia (Kumara, 2006; KLHK, 2018). Dari hasil penutupan lahan 2014 (Kementerian Lingkungan Hidup dan Kehutanan, 2016) terdapat sekitar 27,4 juta ha lahan hutan kering dan primer memiliki potensi habitat rangkong di Kalimantan dan Sumatera (KLHK, 2018)

Membuka Kawasan hutan merupakan ancaman terbesar terhadap lingkungan yang dapat mengganggu fungsi ekosistem yang mendukung kehidupan di dalamnya termasuk untuk rangkong gading yang memiliki karakteristik habitat dan makanan yang spesifik. Lahan kering dan primer yang masih tersisa di Kalimantan dan Sumatera berkisar 12,9 juta hektar (Kementerian Lingkungan Hidup dan Kehutanan, 2016; KLHK, 2018). Akan tetapi hanya sekitar $60 \%$ yang sesuai untuk habitat Rangkong Gading. Daerah yang terdeforestasi sebagian besar diakibatkan oleh alih fungsi hutan menjadi industri kayu, perkebunan dan pertanian (KLHK, 2018). Di Indonesia terjadi pemburuan rangkong gading mulai pada tahun 2012, dimulai sejak adanya permintaan dari pemodal kecil dan kemudian di sebar ke desa-desa oleh para pedagang keliling di sekitar hutan tempat rangkong gading berada. Tingginya permintaan dan keuntungan ekonomi membuat masyarakat melakukan pemburuan terhadap rangkong gading. Pemburuan biasa dilakukan di tempat makan (feeding site) pada saat musim buah ara, karena pada musim tersebut rangkong gading berkumpul (Hardiprakarsa et al., 2013 dalam, KLHK, 2018).

Di Indonesia rangkong gading mulai di konservasi pada tahun 2012 yang dilakukan oleh Rangkong Indonesia. Tetapi usaha konservasi rangkong gading masih menghadapi berbagai macam masalah seperti keterbatasan pengetahuan tentang status dan populasi rangkong gading. Usaha untuk mengantisipasi pemburuan masih belum dilakukan secara optimal, dan pemburuan yang dilakukan di luar batas konservasi (KLHK, 2018).

Untuk mengetahui sebaran habitat potensial untuk rangkong gading, maka perlu dilakukan pengolahan data spasial karena tidak lepasnya kesesuaian habitat dari cakupan ruang dan kondisi geografis di suatu wilayah. Integrasi antara data Penginderaan Jauh (PJ) dengan sistem informasi geografis (SIG) sudah banyak dimanfaatkan untuk evaluasi kualitas dan kesesuaian habitat satwa liar (Latfiana, 2018). Tujuan dari penelitian ini adalah untuk menentukan Kawasan prioritas konservasi rangkong gading di Geopark Silokek, Kabupaten Sijunjung serta analisis variabel apa saja yang memberikan pengaruh yang besar terhadap kesesuaian habitat rangkong gading berdasarkan hasil pengolahan data hasil pengolahan algoritma Maximum Entropy (MaxEnt).

\section{METODE}

\section{Lokasi Penelitian}

Geopark merupakan konsep manajemen pengembangan kawasan berkelanjutan yang menyerasikan keragaman geologi, hayati, dan budaya melalui prinsip konservasi dan Rencana Tata Ruang Wilayah yang sudah ada (Kusuma, 2019). Geopark Silokek ini telah melewati 3 era dalam waktu geologi yang tercermin oleh susunan batuan yang membentuk kawasan.

Selain kekayaan secara geologis, kawasan ini juga kaya akan keberagaman hayati (biodiversitas) dalam aspek konservasi dan perlindungan. Geopark adalah sarana pengembangan di mana konservasi kawasan lindung yang ada dapat diperkuat dan pada saat yang sama kesempatan untuk pembangunan sosial ekonomi masyarakat lokal dapat lebih ditingkatkan secara simultan (Kusuma, 2019). Kawasan Geopark Silokek terletak di Kecamatan Sijunjung dan Kecamatan Simpur Kudus, Kabupaten 
Sijunjunng yang berjarak sekitar 15 kilometer dari Ibukota Kabupaten Sijunjung yaitu Muaro Sijunjung. Dalam penelitian ini, batas wilayah penelitian kami yaitu pada $100^{\circ} 55^{\prime} 8^{\prime \prime}$ BT,
0'33'45'LS - 101³'40'BT,0 0 40'54'LS. Pengambilan titik-titik koordinat berdasarkan temuan rangkong gading yang dijumpai di lapangan.

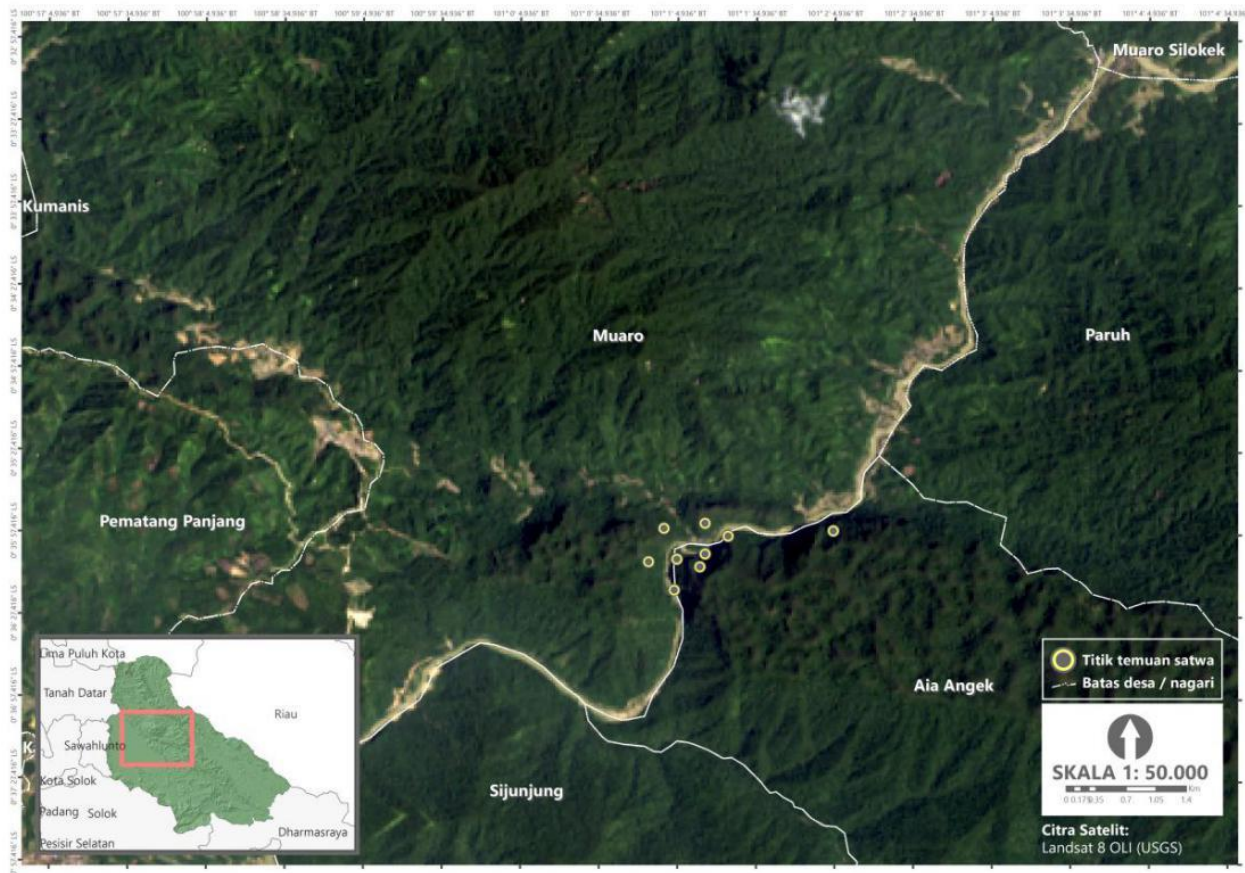

Gambar 1. Lokasi Penelitian di Geopark Silokek, Kabupaten Sijunjung, Provinsi Sumatera Barat (sumber peta : Citra Satelit Landsat 8 OLI)

\section{Pra-Pengolahan Citra}

Penelitian ini memanfaatkan citra digital yang diperoleh dari United States Geological Surveys (USGS) yaitu citra Landsat 8 OLI yang memiliki ketelitian 30x30 meter. Citra Landsat 8 OLI digunakan untuk klasifikasi tutupan dan penggunaan lahan di kawasan Geopark Silokek. Penggunaan algoritma untuk menentukan indeks kerapatan vegetasi atau Normalized Difference Vegetation Index (NDVI) juga diperoleh dari pengolahan citra Landsat 8 OLI dengan memanfaatkan kanal inframerah dan inframerah dekat. Data ketinggian/topografi Shuttle Radar Topography Missions (SRTM) digunakan untuk menentukan elevasi, kemiringan lereng, dan hadapan lereng. Data SRTM memiliki ketelitian atau resolusi 30x30 meter.

\section{Klasifikasi Penggunaan Lahan}

Citra satelit yang diperoleh masih berupa data mentah dan perlu dilakukan klasifikasi. Dalam hal ini metode yang digunakan adalah metode klasifikasi Maximum Likelihood yang merupakan bagian dari klasifikasi terbimbing (supervised). Klasifikasi ini merupakan klasifikasi berbasis piksel. Klasifikasi maximum likelihood merupakan metode klasifikasi yang paling ampuh bila dilengkapi dengan training data yang akurat dan salah satu algoritma yang paling banyak digunakan (Perumal dan Bhaskaran, 2010). Klasifikasi dengan metode ini didasarkan pada pemilihan sampel-sampel yang mewakili kelas tertentu dengan membuat poligon pada setiap kelasnya. Penggunaan lahan yang diklasifikasi yaitu hutan, semak, sawah, badan air, perkebunan, dan permukiman.

\section{Transformasi NDVI (Normmalized Difference Vegetation Index)}

NDVI digunakan untuk menentukan indeks kerapatan vegetasi dengan menggunakan citra satelit. NDVI sering digunakan untuk analisis vegetasi. Kanal yang digunakan dalam transformasi NDVI adalah kanal inframerah (Red) pada band 4 dan kanal inframerah dekat / Near Infrared (NIR) pada 
band 5. Nilai NDVI memiliki nilai yang berkisar antara -1 sampai 1. berikut adalah persamaan NDVI:

$$
N D V I=\frac{(\lambda N I R-\lambda \operatorname{Re} d)}{(\lambda N I R+\lambda \operatorname{Re} d)}
$$

Dimana :

NDVI = Nilai Indeks Vegetasi (antara -1 hingga 1)

$\lambda$ NIR $=$ Nilai reflektan kanal inframerah dekat (Band 5)

$\lambda$ Red $=$ Nilai reflektan kanal inframerah (Band 4)

\section{Euclidean Distance}

Euclidean distance digunakan untuk menghitung jarak lurus setiap sel pada suatu data raster terhadap lokasi sumber (source)/lokasi tujuan (destination) (Indarto dan Faisol, 2012). Data input dalam perhitungan jarak euclidean ini adalah shapefile sungai yang ada di lokasi penelitian yang kemudian dihitung jarak antar sungai satu dengan sungai-sungai lainnya.

\section{Pengolahan Data SRTM}

Data SRTM yang sebelumnya dijelaskan merupakan data yang mengandung informasi elevasi atau ketinggian di suatu lokasi. Nilainilai tiap piksel pada SRTM merupakan nilai yang memuat informasi ketinggian (dalam mdpl). pengolahan data SRTM ini digunakan untuk menentukan elevasi, kemiringan lereng dihitung dengan mengolah nilai ketinggian, aspect yang merupakan arah yang menunjukkan hadapan lereng, serta hillshade yang merupakan gambaran yang memperlihatkan tekstur bentuk permukaan bumi.

\section{Maximum Entropy (MaxEnt)}

Maximum Entropy (MaxEnt) merupakan salah satu metode yang digunakan dalam pemodelan distribusi. Pemodelan dengan menggunakan algoritma Maximum Entropy (MaxEnt) digunakan untuk menentukan kawasan prioritas habitat yang nantinya dapat dijadikan sebagai kawasan prioritas untuk konservasi rangkong gading. Kerangka pemodelan MaxEnt dapat dijelaskan dalam berbagai perspektif (Merow et al., 2013), dalam hal ini digambarkan penerapannya dalam pemodelan probabilitas sebaran habitat rangkong gading. Elith et al. (2006) menyajikan sebuah analisis komprehensif tentang kegunaan algoritma pemodelan yang berbeda mengenai keberadaan data dan menyimpulkan bahwa MaxEnt adalah salah satu algoritma yang paling berguna. Pemodelan MaxEnt sangat potensial untuk mengidentifikasi distribusi dan pemilihan habitat kehidupan liar dengan pertimbangannya bergantung pada lokasi keberadaan (Baldwin, 2009). Dengan fungsi logistik statistik yang dijalankan dengan metode ini, mampu mencari lokasi-lokasi yang memiliki kesamaan dengan titik lokasi keberadaan satwa.

Baldwin (2009) mengemukakan beberapa kelebihan dari algoritma MaxEnt ini, yaitu dari pengambilan sampel bahwa Maxent kurang begitu sensitif dibandingkan pendekatan lain terhadap jumlah lokasi kehadiran yang diperlukan untuk mengembangkan model yang akurat (Elith et al. 2006; Hernandez et al. 2006; Philips et al. 2006), didorong oleh prosedur regularisasi yang mengkompensasi overfitting ketika hanya menggunakan beberapa lokasi. Kelebihan selanjutnya adalah kesalahan pada lokasi yang mana MaxEnt tidak dipengaruhi secara kuat oleh kesalahan spasial tingkat sedang (moderate spatial error). Fitur pemetaan juga merupakan kelebihan dari MaxEnt ini karena output akhir yang berupa peta, MaxEnt menghasilkan peta yang menunjukkan kemungkinan ditemukannya spesies yang kita kaji di kawasan tertentu (Philips et al., 2009). Perhitungan MaxEnt menghasilkan kesesuaian habitat yang ditunjukkan dengan rentang nilai antara 0 sampai dengan 1 (Phillips \& Dudik, 2008), semakin mendekati angka 1 nilai piksel pada peta, maka semakin sesuai untuk habitat rangkong gading.

\section{HASIL DAN PEMBAHASAN}

\section{Faktor Lingkungan}

Faktor lingkungan yang menjadi penentu dalam pemodelan spasial ini datanya diperoleh dari data mentah yang pada dasarnya 
berasal dari data citra Landsat 8 OLI, SRTM, dan data vektor sungai yang diolah menggunakan fitur analisis yang ada pada software ArcGIS. Faktor lingkungan ini diduga memiliki pengaruh terhadap potensi keberadaan rangkong gading. Faktor lingkungan tersebut adalah penggunaan lahan, elevasi, jarak dari sungai, aspect, sungai, dan NDVI.

Penggunaan lahan menggambarkan kondisi fisik yang ada pada lokasi penelitian yang terdiri dari hutan, semak, sawah, permukiman, badan air, dan perkebunan. Dengan adanya penggunaan lahan ini, maka kita dapat mengidentifikasi habitat rangkong gading. Elevasi memiliki pengaruh karena berhubungan dengan keterdapatan vegetasi berdasarkan ketinggian, elevasi pada lokasi penelitian cukup beragam, yaitu pada lembah dengan titik terendah pada 129,96 mdpl dan titik tertingginya pada perbukitan yang memiliki tinggi $1201 \mathrm{mdpl}$. Sungai merupakan faktor penting dalam ketersediaan air dalam mencukupi kebutuhan hidup satwa, oleh karena itu keterjangkauan terhadap sungai merupakan hal yang harus menjadi pertimbangan terhadap kesesuaian habitat, semakin dekat dengan sungai maka semakin mudah air didapat, jarak dari sungai di lokasi penelitian berkisar dari 0 - 3824,26 mdpl. Aspect merupakan fungsi untuk mencari arah dari penurunan yang paling tajam dari masingmasing sel raster dengan nilai outputnya merupakan sudut-sudut arah mata angin, aspect diaplikasikan dalam perhitungan iluminasi matahari pada lokasi penelitian untuk menentukan keragaman hayati pada lokasi tersebut. Parameter kemiringan lereng pada lokasi penelitian sangat kompleks dari kelerengan datar $\left(0^{\circ}\right)$ hingga sangat curam $\left(348,045^{\circ}\right)$, kompleksnya kemiringan lereng ini karena di lokasi penelitian didominasi oleh perbukitan-perbukitan kapur dan struktural serta tebing-tebing terjal, sementara lereng datar cenderung terdapat di sepanjang tepi sungai. Nilai NDVI yang diperoleh dalam penelitian ini adalah dari $-0,227$ sampai 0,600 , apabila nilai vegetasi mendekati 1 maka vegetasi semakin rapat dan apabila mendekati -1 maka akan vegetasi semakin jarang bahkan tidak bervegetasi.
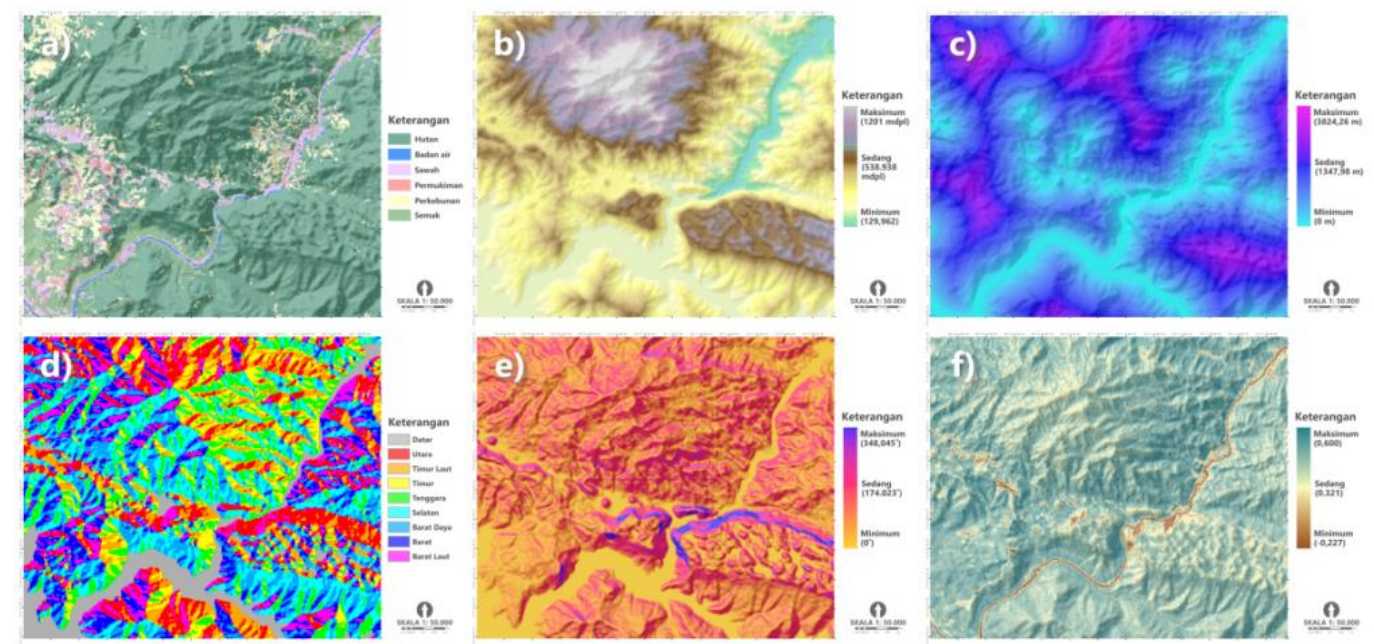

Gambar 2. Peta indikator lingkungan untuk membangun model habitat potensial rangkong gading (Rhinoplax vigil), yaitu: a) penggunaan lahan; b) elevasi/ketinggian; c) jarak dari sungai; d) hadapan lereng (aspect) ; e) kemiringan lereng; dan f) NDVI

\section{Pemodelan Sebaran Habitat Potensial Rangkong Gading (Rhinoplax vigil)}

Pemodelan haitat potensial rangkong gading ini merupakan hasil dari kalkulasi statistik menggunakan algoritma Maximum Entropy (MaxEnt). Maxent menyediakan data output dalam format mentah, kumulatif, dan logistik (Philips et.al, 2008). Nilai yang dihasilkan dari output yang masih dalam format mentah merupakan output utama 
MaxEnt yang nantinya akan diolah dengan Sistem Informasi Geografis (SIG). Format kumulatif merupakan ukuran independen dengan skor di lokasi yang sama dengan probabilitas titik temuan satwa di lokasi tersebut ditambah dengan probabilitas lainnya yang sama atau lebih rendah. Sementara format logistik direkomendasikan karena menghasilkan perkiraan probabilitas kejadian sebagaimana yang diprediksi oleh variabel lingkungan yang disertakan (Philips et.al, 2008) pada saat input data, analisis ini sangat ditentukan oleh faktor variabel lingkungan. Titik-titik koordinat yang merupakan temuan satwa ditambah dengan studi literatur mengenai habitat rangkong gading terletak secara tersebar, tiap-tiap titik terdapat pada nilai tertentu pada masing-masing variabel lingkungan, kemudian analisa MaxEnt akan mencari daerah-daerah lain yang mirip dengan yang terdapat titik-titik koordinat. Dalam sebagian besar kasus, penting untuk mengetahui bagaimana masing-masing variabel memengaruhi keberadaan spesies yang dimodelkan, dan selanjutnya, variabel mana yang memiliki pengaruh terbesar pada model dan bagaimana variabel-variabel ini mempengaruhi kemunculan spesies (Bladwin, 2009). Gambar 3 berikut merupakan hasil pemodelan MaxEnt untuk menentukan habitat potensial rangkong gading di Geopark Silokek. Berdasarkan peta tutupan lahan, kami membagi ke dalam beberapa kelas, namun untuk pemetaan habitat potensial rangkong gading, kami mengelompokkan menjadi dua kategori, yaitu kelas tutupan lahan hutan sebagai kawasan habitat, dan selain hutan merupakan non-habitat. Semakin nilai mendekati 1, maka indeks potensi habitat semakin sesuai yang ditandai dengan semakin berwarna hijau gelap pada peta dan apabila nilainya mendekati 0 maka indeks potensi habitat semakin rendah atau kurang sesuai ditandai dengan warna yang semakin kuning.

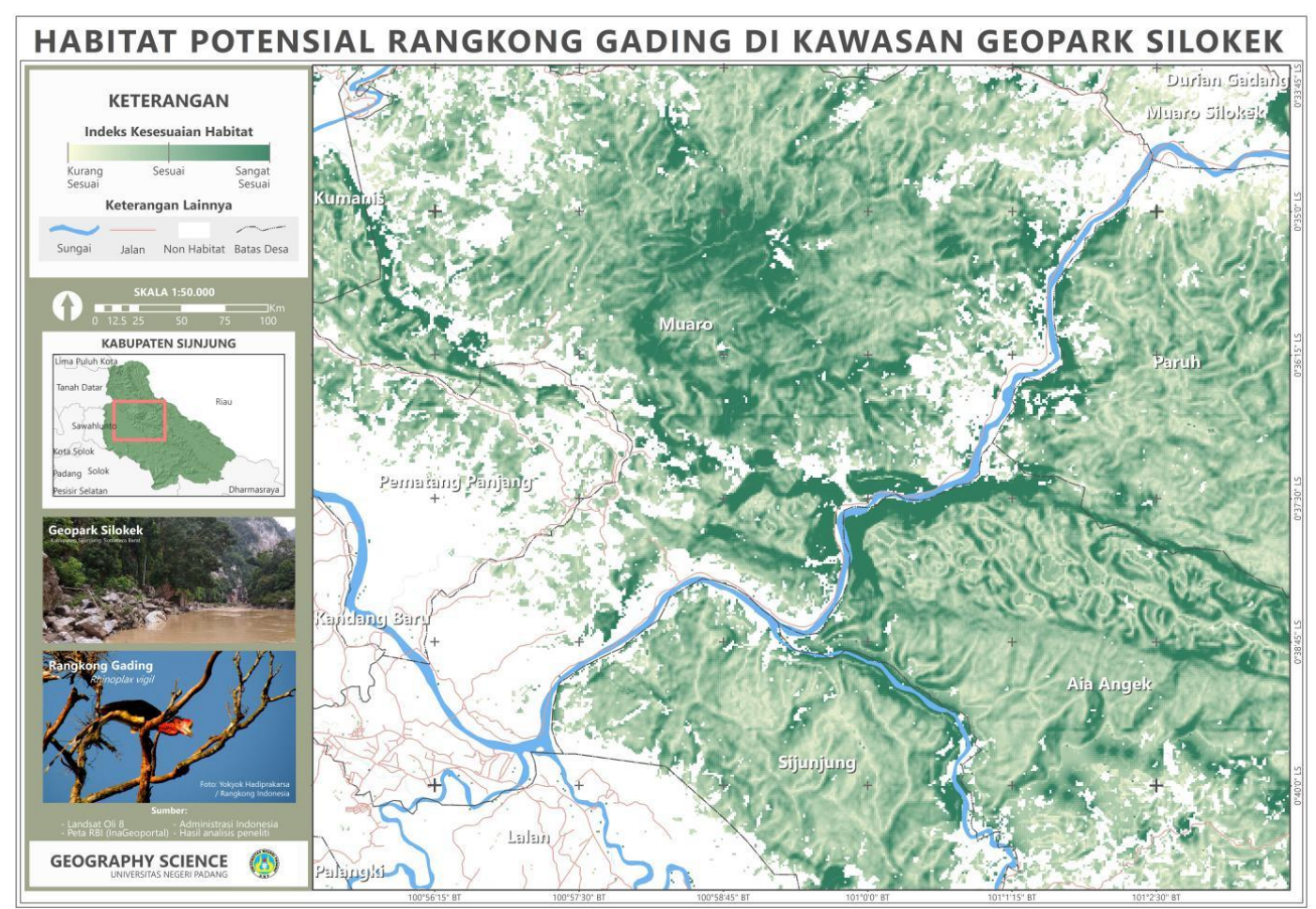

Gambar 3. Peta pemodelan probabilitas sebaran habitat yang potensial untuk rangkong gading di kawasan Geopark Silokek, Kabupaten Sijunjung

\section{Persentase Pengaruh Variabel Lingkungan}

Persentase pengaruh variabel lingkungan menunjukkan sebesar apa kontribusi masingmasing parameter lingkungan yang menentukan potensi kawasan untuk habitat rangkong gading di Kawasan Geopark Silokek. Persentase ini dihasilkan karena 
berdasarkan lokasi temuan satwa di lapangan dan studi literatur berkaitan mengenai habitat rangkong gading.

Pada diagram berikut (Gambar 4) menunjukkan persentase kontribusi variabel dalam pemodelan ini. Ditemukan bahwa tiga variabel teratas yang memiliki persentase kontribusi paling tinggi, yaitu Penggunaan Lahan (35,5\%), sungai $(25,6 \%)$, dan kemiringan lereng $(24,4 \%)$. Ketiga variabel tersebut yang mendominasi penentuan kawasan habitat potensial rangkong gading dalam pemodelan ini.

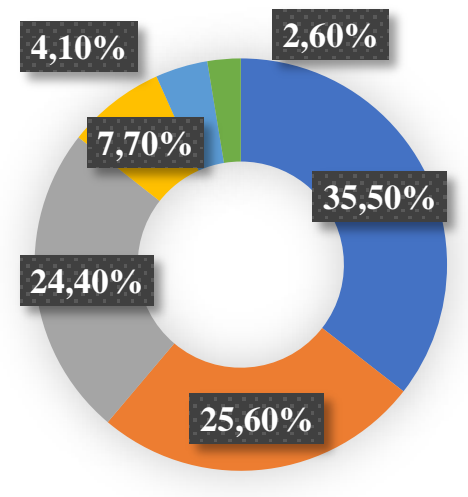

\author{
- Penggunaan Lahan \\ - Jarak dari Sungai \\ Kemiringan Lereng \\ - Aspect \\ - NDVI \\ - Elevai
}

Gambar 4. Diagram persentase kontribusi variabel lingkungan dalam pemodelan menggunakan MaxEnt

Penggunaan lahan merupakan persentase paling besar dalam pemodelan ini. Penggunaan lahan yang menjadi penentu tingginya persentase kontribusi variabel lingkungan adalah kelas hutan, karena semua titik koordinat yang diolah dalam MaxEnt terletak di dalam hutan yang mana di sini merupakan ekosistem yang sangat sesuai untuk habitat rangkong gading karena terdapat banyak pohon-pohon berukuran besar, baik diameter maupun tingginya sehingga sangat aman untuk ditinggali oleh rangkong gading. Tingginya biodiversitas yang terdapat dalam hutan menyediakan banyak sumber makanan bagi rangkong gading, terutama buah ara/ficus. Di Sumatera diperkirakan 98\% pakannya berupa buah ara/ficus (Hadiprakarsa \& Kinnaird, 2004). Pada Gambar 3, semua habitat rangkong baik dari yang kurang sesuai maupun sangat sesuai adalah kelas penggunaan lahan hutan, sementara nonhabitat merupakan kelas tutupan lahan yang bukan hutan (sawah, semak, perkebunan, lahan terbangun, dan sungai) dan tidak ada potensi untuk habitat rangkong gading di Geopark Silokek. Kawasan Geopark Silokek dialiri oleh sungai besar yaitu Batang Kuantan yang berinteraksi langsung dengan tebing-tebing tinggi yang dan perbukitan dengan hutan lebat membuat variabel jarak dari sungai ini memiliki persentase tertinggi setelah penggunaan lahan. Karena letak sungai yang berbatasan langsung dengan hutan, maka hal ini menunjukkan tingginya kebutuhan satwa terhadap air. Pada peta, kesesuaian habitat pada indeks sangat tinggi cenderung berada di sepanjang aliran sungai. Sungai yang merupakan pasokan energi dan sumber penghidupan bagi apa saja yang ada disekitarnya termasuk juga rangkong gading. Di lapangan, ditemukan rangkong gading yang terbang di sekitar sungai yang diduga tempat tinggalnya berada di lereng curam yang ada di pinggir sungai. Kelerengan yang curam mendominasi kawasan penelitian karena morfologi yang berupa perbukitan, baik perbukitan karst (kapur) ataupun perbukitan struktural. Indeks kesesuaian habitat sangat tinggi pada peta juga terletak pada lereng dengan kemiringan yang tinggi, yang merupakan tempat yang aman bagi satwa. Sementara pada kebanyakan kelas lereng rendah (datar dan landai) sangat tidak sesuai bagi rangkong gading, pada peta tutupan lahan tampak pada lereng datar yang telah dimanfaatkan untuk permukiman, perkebunan, dan sawah. 
Pada Gambar 5 ditampilkan grafik respon terhadap variabel lingkungan dengan kontribusi tertinggi. Penggunaan lahan dengan kelas hutan (pada grafik ditandai dengan kode 1) yang merupakan penentu tingginya kontribusi pada variabel ini. Jarak dari sungai dilihatkan pada grafik dengan semakin mendekati nilai 0 meter ke sungai, maka nilai logistik semakin mendekati 1 yang

menandakan pentingnya kedekatan jarak ke sungai, sebaliknya jika menjauhi sungai maka grafik akan menurun mendekati nilai logistik 0. Kelerengan dengan kemiringan yang semakin curam digambarkan dengan naiknya grafik mendekati nilai logistik 1 seiring bertambah curamnya lereng dan semakin mendekati nilai logistik 0 apabila lereng semakin datar. a)

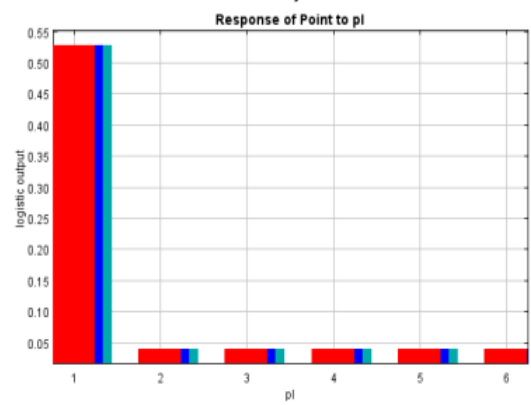

b)

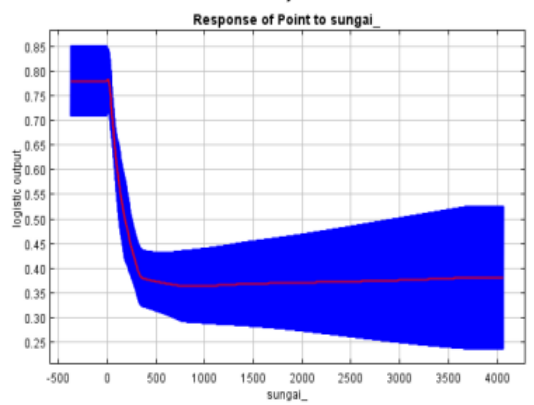

Gambar 5. Grafik yang menunjukkan respon terhadap variabel lingkungan berkontribusi tinggi; (a) Penggunaan lahan, (b) Jarak dari sungai, dan (c) Kemiringan lereng

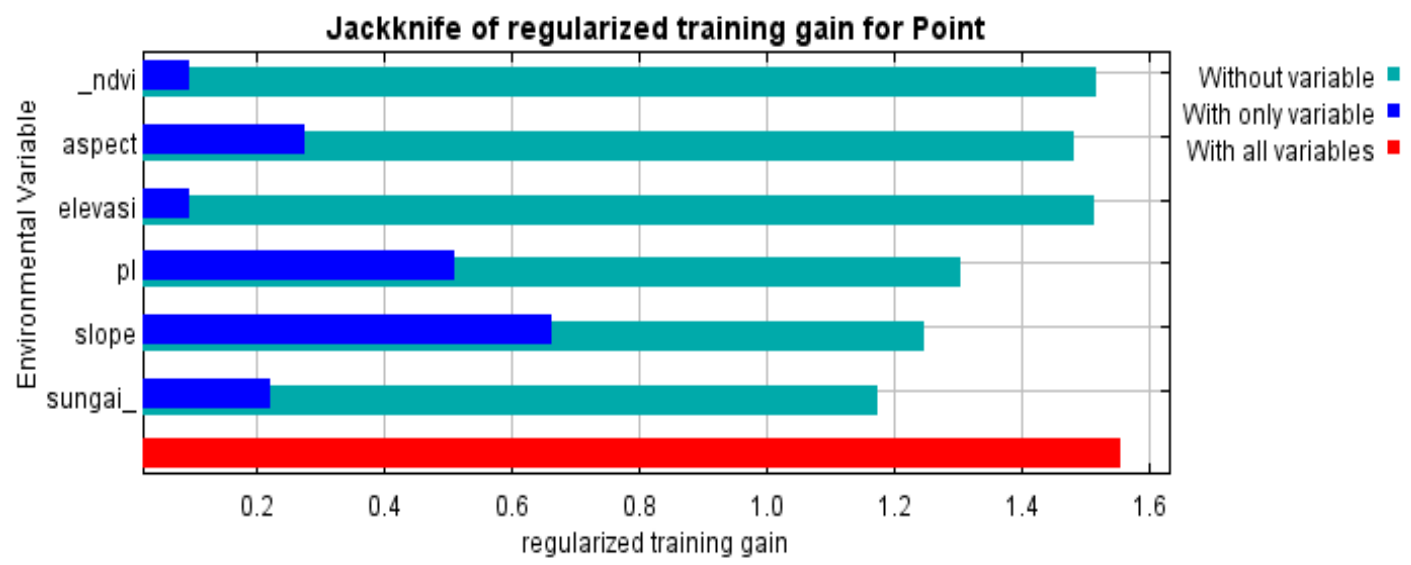

Gambar 6. Hasil uji Jackknife replikasi pemodelan MaxEnt

Gambar 6 menunjukkan hasil uji Jackknife dari variabel penting. Variabel lingkungan dengan hasil tertinggi yaitu kemiringan lereng yang merupakan informasi terpenting terhadap performa model. Kemudian variabel lingkungan yang paling berpengaruh menurunkan hasil jika diabaikan adalah jarak dari sungai yang berarti variabel ini merupakan informasi penting yang tidak terdapat pada variabel lainnya.

\section{PENUTUP}

Berdasarkan hasil dari analisis yang dilakukan bahwa probabilitas rangkong gading faktor lingkungan yang berpengaruh yaitu:

1. Penggunaan lahan yang terdiri dari hutan, semak, sawah, permukiman, badan air, dan perkebunan,

2. Kemiringan lereng dengan kelerengan datar $\left(0^{\circ}\right)$ hingga sangat curam $\left(348,045^{\circ}\right)$,

3. Elevasi dengan titik terendah 129,96 mdpl dan titik tertingginya pada perbukitan yang memiliki tinggi $1201 \mathrm{mdpl}$,

4. Jarak dari sungai berkisar dari 0 - 3824,26 mdpl, 
5. Aspect yang digunakan perhitungan iluminasi matahari,

6. NDVI dari -0,227 sampai 0,600

Probabilitas rangkong gading berdasarkan pemodelan Maxent, berada pada di Kawasan perbukitan hutan lindung bagian utara dan timur laut yang ditunjukkan dengan nilai mendekati 1, maka indeks potensi habitat semakin sesuai yang ditandai dengan semakin berwarna hijau gelap pada peta dan apabila nilainya mendekati 0 maka indeks potensi habitat semakin rendah atau kurang sesuai ditandai dengan warna yang semakin kuning.

\section{DAFTAR PUSTAKA}

Baldwin, R. (2009). Use of maximum entropy modeling in wildlife research. Entropy, 11: 864 - 866.

Elith, J., Graham C.H., Anderson, R.P., Dudik, M., Ferrier, S., Guisan, A., Hijmans, R.J., Huettmann, F., Leathwick, J.R., Lehmann, A., Li, J., Lohmann, L.G., Loiselle, B.A., Manion, G., Moritz, C., Nakamura, M., Nakazawa, Y., Overton, J.M., Peterson, A.T., Phillips, S.J., Richardson, K., Scachetti-Pereira, R., Schapire, R.E., Soberon, J., Williams S., Wisz, M.S., \& Zimmermann, N.E. (2006). Novel methods improve prediction of species' distributions from occurrence data. Ecography 29(2):129-151.

Kumara, I. (2006). Karakteristik spasial habitat burung rangkong di Taman Nasional Danau Sentarum. Tesis Sekolah Pascasarjana Institut Pertanian Bogor: Bogor.

Kusuma, D. (2019). Geopark Silokek Sijunjung Menuju UNESCO Global Park. Jurnal Pembangunan Nagari, Vol. 4 (1): 17-32.

Hadiprakarsa, Y., \& Kinnaird. M.F. (2004). Foraging characteristics of an assemblage of four Sumatran hornbill species. Bird Conservation International 14:S53- S62-S53-S62.
Hernandez, P.A., Graham, C.H., Master, L.L., Albert, D.L. (2006). The effect of sample size and species characteristics on performance of different species distribution modeling methods. Ecography Vol. 29, 773-785.

Indarto, Faisol, A. (2012). Konsep dasar analisis spasial. Penerbit ANDI: Yogyakarta. (2018).

Latifiana, K. (2018). Pemetaan potensial Hepterofauna pada daerah terdampak erupsi gunung Merapi 2010. Seminar Nasional Geomatika 2018: Penggunaan dan Pengembangan Produk Informasi Geospasial Mendukung Daya Saing Nasional : $497-510$.

KLHK. (2018). Strategi Dan Rencana Aksi Konservasi Rangkong Gading (Rhinoplax Vigil) Indonesia 20182028.

Merow, C., Smith, M.J., Silander, J.A. (2013). A practical guide to MaxEnt for modeling species distributions: what it does, and why inputs and settings matter. Ecography 36(10):1058-1069. https://doi.org/10.1111/j.16000587.2013.07872.x

Perumal, K., \& Bhaskaran, R. (2010). Supervised Classification Performance of Multispectral Images. Journal of Computing, Vol. 2(2): 124:129.

Phillips, S. J., \& Dudik, M. (2008). Modeling of species distribution with Maxent: new extensions and a comprehensive evaluation. Ecography, 31: 161-175.

Phillips, S.J., Anderson, R.P., \& Schapire, R.E. (2006). Maximum entropy modeling of species geographic distributions. Ecol. Model.190: 231259.

Phillips, S.J. A brief tutorial on Maxent, versions: 3.3.1. Available online: http://www.cs.princeton.edu/ schapire/ maxent/ (accessed on August 19, 2009). 